\title{
Four Nations Going Their Own Ways? Citizenship Education in the United Kingdom
}

Quatre nations suivant leur propre trajectoire? La citizenship education au Royaume-Uni

\section{Anne Beauvallet}

\section{OpenEdition}

\section{Journals}

Electronic version

URL: http://journals.openedition.org/rfcb/727

DOI: $10.4000 / \mathrm{rfcb} .727$

ISSN: 2429-4373

Publisher

CRECIB - Centre de recherche et d'études en civilisation britannique

Electronic reference

Anne Beauvallet, « Four Nations Going Their Own Ways? Citizenship Education in the United Kingdom », Revue Française de Civilisation Britannique [Online], XXI-1 | 2016, Online since 18 July 2016, connection on 01 May 2019. URL : http://journals.openedition.org/rfcb/727 ; DOI : 10.4000/rfcb.727

This text was automatically generated on 1 May 2019.

\section{c) $(9)$}

Revue française de civilisation britannique est mis à disposition selon les termes de la licence Creative Commons Attribution - Pas d'Utilisation Commerciale - Pas de Modification 4.0 International. 


\title{
Four Nations Going Their Own Ways? Citizenship Education in the United Kingdom
}

\author{
Quatre nations suivant leur propre trajectoire? La citizenship education au \\ Royaume-Uni
}

Anne Beauvallet

\section{Introduction}

1 In his study on Citizenship in Britain, Derek Heater analyses the works of Thomas Starkey and highlights the key role to be played by schools for future citizens ${ }^{1}$. Bearing this in mind, we have chosen to focus on citizenship education (CE) in the UK at secondary school level, that is at about Key Stages 3 and 4 (see diagram below), ages 11 or 12 to 16 . Our objective is to study the development of CE which started in the 1990s, that is nearly at the same moment as devolution. Devolution has ensured that the four nations which make up the UK are fully in charge of their own education systems and each has included $\mathrm{CE}$ in its curriculum. What are the differences and common characteristics of this subject across the UK? Can it constitute a common ground for all British school children? This article falls into three parts. First, we will tackle the status of CE, that is its place in the secondary school curriculum. The second part deals with the approaches to CE, namely the ways in which the four nations have defined it, its underlying values and the educational strategies thus adopted. The third part explores the implications of CE for the UK and the case of Scotland with the 2014 independence referendum. The names given to CE vary across the UK: Citizenship Education in England (CE); Education for Sustainable Development and Global Citizenship in Wales (ESDGC); Local and Global Citizenship in Northern Ireland (LGC); global citizenship in Scotland.

Citizenship Education in Secondary Education in the UK 


\begin{tabular}{|l|l|l|l|}
\hline & Key Stages & School Years & Ages \\
\hline England & KS3 and KS4 & $7-9$ and $10-1$ & 11 to 14 and 14 to 16 \\
\hline Wales & KS3 and KS4 & $7-9$ and $10-1$ & 11 to 14 and 14 to 16 \\
\hline Northern Ireland & KS3 and KS4 & $8-10$ and $11-2$ & 11 to 14 and 14 to 16 \\
\hline Scotland & S1 to S5 & $7-11$ & $11-2$ to 16 \\
\hline
\end{tabular}

\section{Status of Citizenship Education}

2 To deal with the status of citizenship education, several questions need to be raised: is CE on a statutory basis? Is it a subject in its own right or is it a cross-curricular theme? England and Northern Ireland have put CE on a statutory basis and treat it as a subject. Wales considers it as a subject which is not statutory. In Scotland, CE is not a statutory subject but a cross-curricular theme.

In England, thanks to strong commitment from New Labour politicians, David Blunkett in particular, the Advisory Group on Citizenship chaired by Bernard Crick issued its final report in 1998. ${ }^{2}$ The New Labour Government followed the report's main recommendations and in $2002 \mathrm{CE}$ became a foundation subject for pupils aged 11 to 16 , thus making it statutory. ${ }^{3}$ The Conservative-Liberal Democrat coalition Government seriously considered downgrading $\mathrm{CE}$ to the basic curriculum and this was opposed by the Association for Citizenship Teaching and an umbrella organisation called Democratic Life. The latter's founding members include Amnesty and the Hansard Society and it is supported by the Law Society. In February 2013, Education Secretary Michael Gove announced CE would remain a National Curriculum foundation subject in secondary schools. ${ }^{4}$

In Northern Ireland, the 1998 Good Friday agreement referred to the necessary "promotion of a culture of tolerance at every level of society" 5 . This is why in 1999 the Northern Ireland Council for the Curriculum, Examinations and Assessment (CCEA) introduced the Social Civic and Political Education Project (SCPE). The Project was gradually extended to include all schools at Key Stages 3 and 4 in 2002. This ensured the development of Local and Global Citizenship (LGC) as a strand of Learning for Life and Work (LLW) and LGC was put on a statutory basis with the Education (Curriculum Minimum Content) Order (Northern Ireland) 2007. In a 2007 document, the Council for the Curriculum, Examinations and Assessment (CCEA) lists three "curriculum objectives":

The Northern Ireland Curriculum should provide learning opportunities for each young person to develop as: 1 . an individual; 2 . a contributor to society; and 3. a contributor to the economy and the environment. ${ }^{6}$

This is why LGC can also be considered by teachers as a cross-curricular theme:

Teachers can assist the development of young people's concept of citizenship by providing frequent opportunities, within and across the curriculum, for young people to think about and experience what it means to act democratically. ${ }^{7}$

In Wales, Education for Sustainable Development and Global Citizenship (ESDGC) as a subject is part of Personal and Social Education (PSE). The latter became statutory in the 2004 curriculum, unlike ESDGC itself. ESDGC is also cross-curricular as pointed out by the 
Department for Children, Education, Lifelong Learning and Skills in 2008: "Although ESDGC is highlighted as one of the themes for PSE, it is important to remember that it runs through all the other themes."

In Scotland, Global Citizenship (GC) is not a statutory subject but a crucial crosscurricular theme. In 2004, the Curriculum for Excellence (CfE) identified "four capacities": "Our aspiration for all children and for every young person is that they should be successful learners, confident individuals, responsible citizens and effective contributors to society and at work." That is why, in the words of Michael Russell MSP, Cabinet Secretary for Education and Lifelong Learning, "global citizenship is not an add-on to Curriculum for Excellence - it is central to it." ${ }^{10}$ The Scottish Government has even initiated a Scottish Education Award for Global Citizenship, which was awarded to Mearns Primary in East Renfrewshire in $2011^{11}$ and to Biggar Primary School in South Lanarkshire in 2014, for example.

CE qualifications are only available in England and they do not exist per se as they are part of a wider subject in the other regions. In England, General Certificates of Secondary Education (GCSEs) for Citizenship Studies were launched in 2008 and have been overseen by the Office of Qualifications and Examinations Regulation (Ofqual). In Northern Ireland, there is a GCSE in Learning for Life and Work and it includes aspects of citizenship, personal development and employability. In Wales, there are the Personal and Social Education GCSE and the Personal and Social Education Welsh Baccalaureate Qualification. Global Citizenship in Scotland features in the National qualifications in Geography and Modern Studies introduced in 2014.

\section{Approaches to CE}

British approaches to CE are to be analysed through three key elements: the way CE is defined and its key themes; the role values play in it; and the teaching and learning strategies that the different approaches entail. Although the four nations use comparable underlying themes, they express them in specific ways. In England, here is the definition provided by the 1998 Crick Report: "in essence it has three strands: social and moral responsibility, community involvement and political literacy." ${ }^{12}$ In 2007, the Diversity and Citizenship Curriculum Review chaired by Sir Keith Ajegbo recommended that "issues of identity and diversity are addressed explicitly." ${ }^{13}$ This is why in September 2008 a new strand was added, Living together in the UK. The latter is currently tackled at Key Stage $4 .^{14}$ According to the Northern Ireland Council for the Curriculum, Examinations and Assessment (CCEA):

Local and Global Citizenship is important because it helps young people learn how to participate positively in society, to influence democratic processes and to make informed and responsible decisions as local and global citizens throughout their lives. ${ }^{15}$

It is underpinned by "themes" such as "Human Rights and Social Responsibility; Diversity and Inclusion; Equality and Social Justice; Democracy and Active Participation." ${ }^{16}$

The Welsh Department for Children, Education, Lifelong Learning and Skills has since 2008 defined Education for Sustainable Development and Global Citizenship in the following way:

ESDGC is about the things that we do every day. It is about the big issues in the world - such as climate change, trade, resource and environmental depletion, 
human rights, conflict and democracy, - and about how they relate to each other and to us. ${ }^{17}$

Its underlying concepts are "Commitment and Leadership; Learning and Teaching; Organisational Management; Partnerships and Community; and Research and Monitoring." 18

11 In 2010, Learning and Teaching Scotland, a non-departmental public body in charge of the curriculum, considered global citizenship as part and parcel of the Curriculum for Excellence:

Developing global citizenship within Curriculum for Excellence is about recognising our responsibilities towards each other and the wider world. The outcome will be our children and young people as global citizens, able to take up their place in the world, contribute to it confidently, successfully and effectively, understanding the rights and responsibilities of living and working in a globalised world. ${ }^{19}$

It is based on the following themes: "education for citizenship, international education and sustainable development education." 20

\section{CE and values}

This is the second issue related to approaches to CE in the UK and two perspectives are to be found. In Wales and in England, values are not absent, as the following excerpt from the 1998 Crick Report shows: "Citizenship education [...] is not an end in itself, even if it will involve learning a body of knowledge, as well as the development of skills and values." 21 The same attitude can be found in this excerpt from the 2008 Personal and Social Education Framework for 7 to 19-year-olds in Wales: "Learners acquire the skills, values and knowledge that equip them to participate in decision-making within their communities, locally, nationally and globally." 22

Values are thus considered as peripheral to CE in England and Wales. In contrast, in Northern Ireland and Scotland, values are central to it. They are listed by the Northern Ireland Council for the Curriculum, Examinations and Assessment (CCEA): "Local and Global Citizenship is fully supportive of the following concepts: diversity, inclusion, equity, respect, human rights and participation." ${ }^{23}$ According to Learning and Teaching Scotland "education to develop global citizenship is values-driven." 24 These values are "wisdom, justice, compassion, integrity." 25

\section{Educational approaches to CE}

Educational approaches are "holistic" in Wales, Scotland and Northern Ireland as they involve whole schools, specific teaching methods and student participation. Let us deal with each of these approaches. The Welsh Department for Children, Education, Lifelong Learning and Skills has advocated "a broad, balanced holistic approach to Personal and Social Education which [...] includes all the planned learning experiences and other opportunities which are features of the ethos and community life of the school." ${ }^{26}$ In a 2010 article, Sheila Bennell and David Norcliffe point out there has been "an emphasis on skills and pupil-centred learning". ${ }^{27}$ This has also entailed growing student participation in school organisation. The 2005 School Councils Regulations made school councils mandatory and since 2010 pupil participation in school decisions has been a statutory requirement.

Learning and Teaching Scotland has taken one step further by defining global citizenship as "a holistic approach." 28 Teaching has been based on "democratic and participative methodologies to learning and teaching" which "recognise children and young people as citizens 
now, not in waiting." ${ }^{29}$ This is why "planning and decision-making processes are inclusive and participative, involving learners and the wider school community" ${ }^{30}$, although it must be noted that numerous as pupil councils may be in Scotland they are not yet mandatory.

In Northern Ireland, Local and Global Citizenship "should be linked to and supported by: the school ethos, other subjects, whole school events, community links, experiences and events and extra curricular activities". ${ }^{31}$ Teaching methods are also child-centred and the Northern Ireland Council for the Curriculum, Examinations and Assessment (CCEA) describes them as "enquiry based", "collaborative" and "creative." ${ }^{32}$ As in Scotland, "the precept of the pupil as a citizen... not a citizen in waiting" 33 has been prevalent but opportunities for students to engage in decision-making are limited:

Local and Global Citizenship can: encourage pupils to participate positively in school and community life; [...] encourage pupils to take greater individual and group responsibility for their learning; [...] support a positive and inclusive classroom and school ethos. ${ }^{34}$

The English approach, in contrast, is not holistic but subject-based. The whole-school approach is referred to in the 1998 Crick Report but the recommendations of the Advisory Group on Citizenship are rather low-key: "We unanimously recommend that: schools consider the relation of citizenship education to whole school issues including school ethos, organisation and structures." ${ }^{35}$ The same can be said about the 2007 Ajegbo Report:

Our conclusion is that in order to develop the recommended approaches in our report, and to encourage all schools to be involved, there needs to be a focus on whole-school exploration of identities, diversity and citizenship. ${ }^{36}$

The 1998 Crick Report called for "active, participatory activities and experiences where the emphasis is on learning through action" ${ }^{{ }^{37}}$ but the current strategy can be called didactic. Released in September 2013, the National Curriculum in England Framework Document first details the skills to be acquired, before adding the list of items that "[p]upils should be taught about"38. Education Secretary Michael Gove might have played a role in this as he has repeatedly favoured traditional teaching methods ${ }^{39}$. The Crick Report did not make radical recommendations on involving students in school organisation ${ }^{40}$ and neither did the 2007 Ajegbo report. ${ }^{41}$ In March 2007, MPs called for schools" "statutory duty to establish a student council" 42 but this call has gone unheeded as student councils are not yet compulsory in England, thus precluding any progress in the participation of students in school organisation across the country.

\section{CE and the UK}

19 After defining the status and the educational strategies that the four nations have adopted regarding CE, we will analyse its implications for the UK, first through its political background and impact and second through its significance for the UK as an entity.

\section{Political background and impact}

The rise of CE in England, Wales and Scotland was set in a similar background in that it was characterised by concerns over low participation and a lack of trust in politicians and politics among young people. This is why the London, Cardiff and Edinburgh executives 
considered that CE could help tackle these issues. The political background in Northern Ireland has been completely different and this is why we will deal with it separately.

In England, the 1998 Crick report highlighted "worrying levels of apathy, ignorance and cynicism about public life." 43 In Scotland according to a MORI poll, in the 2001 general elections, " $39 \%$ of $18-24$ year olds voted." ${ }^{44}$ In the 2003 Welsh Assembly elections, "around 80 per cent of registered voters aged 18-34 did not use their vote" as head of the Assembly's Local Government and Public Services Committee Ann Jones pointed out in the foreword to the 2006 'Electoral Arrangements in Wales' Scrutiny Project. ${ }^{45}$

The impact of CE in England was explored at length with the Citizenship Education Longitudinal Study launched in 2001. In 2010, its Eighth and Final Report presented a "mixed picture":

On the one hand, there has been a marked and steady increase in young people's civic and political participation and indications that these young people will continue to participate as adult citizens. In contrast, there has been a hardening of attitudes toward equality and society, a weakening of attachment to communities and fluctuating levels of engagement, efficacy and trust in the political arena. ${ }^{46}$

To this day, one survey on the impact of CE in England, Scotland and Wales can be traced: it was released by the National Foundation on Educational Research (NFER) in 2012. This online study of people aged 18-25 (of whom 1,055 respondents went to school in England, 426 in Scotland and 391 in Wales) "found that the Scottish respondents may have a better recall of citizenship even though they do not always describe it as citizenship." ${ }^{47}$ It also:

[...] uncovered evidence of a 'legacy' of citizenship teaching - 'particularly in terms of the topics that (young people) remember being taught about and the perceived depth of that teaching'; again, Scots were found to be the most likely to have benefited. ${ }^{48}$

Another consequence of CE was the "'massive number' of fundraising schemes in Scottish schools". ${ }^{49}$

The issue of political literacy has been raised in the three countries. Ben Kisby and James Sloam identify it as a problem primarily for Scotland and Wales since CE is not statutory there: "In Scotland and Wales, in contrast, commitment to political literacy is patchier." ${ }^{50}$ In the latest edition of Scottish Education, Gert Biesta highlights the risks CE in Scotland has entailed:

The Scottish approach has a tendency to focus on the individual rather than the collective; on the social more than on the political dimensions of citizenship; on social activity more than on political action; and on a community of sameness more than a community of difference. ${ }^{51}$

This is why Biesta argues that students could find themselves limited in their "concerns and responsibilities" and CE in Scotland could be "depoliticised". ${ }^{52}$ Yet, political literacy is also considered as inadequate in England since it was included in the recommendations of the 2010 Eighth and Final Report from the Citizenship Education Longitudinal Study: "It is also suggested that consideration is given to providing citizenship education through to age 18 and providing support and training for the 'political literacy' strand and for embedding citizenship learning in schools." ${ }^{33}$ Ben Kisby and James Sloam consider that the English political system acts as a direct hindrance:

The centralized system in England, for example, shows how political institutions can act as a barrier to participation - all the good work done through citizenship education can be undermined by a political system that reduces incentives for participation through a lack of access (to political influence) and rewards (positive impacts from engagement). In this respect, the devolved parliament in Scotland 
and the devolved assemblies in Wales and Northern Ireland are at least closer to the people, i.e. they are smaller units of government that, at least in principle, offer more promising avenues for citizens to influence the political process." ${ }^{44}$ British school children. Northern Ireland, because of its specificity, cannot be included in this line of thought. We studied the contents of $\mathrm{CE}$ as a subject in England and Wales and as a cross-curricular theme in Scotland and found very little about the other regions and their links. In England for instance, the "four nations" are only part of the Key Stage 4 curriculum:

Pupils should be taught about: [...] the different electoral systems used in and beyond the United Kingdom; [...] the diverse national, regional, religious and ethnic identities in the United Kingdom and the need for mutual respect and understanding..$^{58}$

Regarding CE in Wales, no specific reference to the rest of the UK, or to the UK as a common entity, could be traced. In fact since the early 1990s the Welsh curriculum has been influenced by Welshness and by two documents in particular. In 1991, the first, entitled Community Understanding, was published. It is based on "a set of guidelines advocating a clear focus on a definition of a community". ${ }^{59}$ Released in 1993, the second document, entitled Developing a Curriculum Cymreig,

placed an emphasis upon the need for schools to use opportunities throughout the curriculum to develop distinctively Welsh elements of culture, whilst acknowledging the need to celebrate diversity. ${ }^{60}$

The two perspectives cannot be equated:

These traditions differ in context and outcome; in south Wales there were suspicions of the growth of an elitist cultural nationalism [...]; while Welsh speakers in the rural north and mid Wales felt excluded by a political structure that favoured the more industrial and English-speaking majority in the south. ${ }^{61}$ 

and Northern Ireland, Education for Sustainable Development and Global Citizenship (ESDGC) is a non-statutory subject in Wales and global citizenship is a cross-curricular theme in Scotland. A didactic subject-based perspective has been adopted in England as opposed to a whole-school strategy and experiential learning in Wales, Scotland and

Each perspective has thus framed the approach to $\mathrm{CE}$ in Wales, making it distinct from CE as taught in the rest of the UK.

In the Scottish approach to CE, no reference to the rest of the UK or to the UK as a common entity could be found. In its Corporate Plan 2013-2016, Education Scotland, a Scottish Government executive agency, presents Scots as members of the wider world rather than of the UK:

The purpose of the curriculum [is] to enable all young people to become [...] responsible citizens [...] able to develop knowledge and understanding of the world and Scotland's place in it. ${ }^{62}$

In the same document, Education Scotland lists its "strategic objectives". Here is one of them: "We take pride in a strong, fair and inclusive national identity". ${ }^{63}$ This is why the 2014 referendum on Scottish independence is interesting. For the first time, people aged 16 and 17 were allowed to vote and CE may have had some influence on their participation and their choice. It is also interesting because it raises serious political questions about the UK. In January 2014, Sheila Riddell, director of the University of Edinburgh's Centre for Research in Education Inclusion and Diversity, warned: "teachers may shy away from covering the referendum on Scottish independence in class because they are wary of appearing politically biased". ${ }^{64}$ This is why the Centre for Research in Education Inclusion and Diversity issued materials to help teachers who are "keen to access resources which [...] do not emanate from the Better Together or YES campaigns" ${ }^{65}$ In August 2014, 27 of Scotland's 32 councils restricted access to the two sides ${ }^{66}$ and this was criticised by people such as Susan Quinn, a teacher, union activist and yes campaigner: "This is an educational opportunity that could be missed. The young people want to engage in this important decision for their future." ${ }^{\prime 67}$ Such a decision by most Scottish councils in August 2014 however did not prevent students' involvement in debates. As pointed out in the Autumn-Winter 2014-15 issue of Stride, the Global Citizenship magazine for schools, by Kim McCauley:

Unsurprisingly, our young people took the baton and ran with it. In the run up to the referendum, we had the thrilling political spectacle of 16 and 17 year old firsttime voters, filling the Hydro in Glasgow and grilling campaigners from both sides on the issues that mattered to them. ${ }^{68}$

This was borne out by the December 2014 Electoral Commission report: "109,593 16 and 17 year olds were included on the registers by the registration deadline and $75 \%$ of those we spoke to claimed to have voted" 69 . Such a figure is lower than the average turnout (85\%) but it is higher than among 18 -to-24 year-olds $\left(54 \%^{70}\right)$. It must be noted that the SNP has adopted no particular stance on global citizenship before or since the 2014 referendum. The time of the successive SNP Education Secretaries, Michael Russel and Angela Constance, has mostly been spent on the implementation of Curriculum for Excellence and the National Improvement Framework and this implementation has not been without its problems.

\section{Conclusion}

CE and Local and Global Citizenship (LGC) are statutory subjects in respectively England 
Northern Ireland. When it comes to the political background to CE, Northern Ireland stands apart since it stems from the need to establish a stable basis for peace. England, Wales and Scotland have promoted CE as a possible solution to the low participation of young people in politics but it cannot be considered as a common ground across Great Britain since Wales and Scotland have logically used CE to further their distinctive identities. Through numberless school debates and a relatively high turnout among 16and 17-year-olds, global citizenship seems to have played a positive part in the 2014 Scottish independence referendum. It could also affect the young voters who will cast their ballots for the first time for the Scottish Parliament elections in May 2016.

\section{BIBLIOGRAPHY}

Advisory Group on Citizenship, Education for Citizenship and the Teaching of Democracy in Schools, Final Report of the Advisory Group on Citizenship. London, QCA, 1998, 85 p.

Andalo, Debbie, "MPs call for improved citizenship classes", The Guardian, 8 March 2007.

Arlow, Michael, Chapter 6 "Education for local and global citizenship: the Northern Ireland experience" pp.89-100 in Education Above All, Conference in Doha, Qatar, July 2012.

Belgutay, Julia, "Is independence debate too hot to handle in class?", Times Education Supplement Scotland, 17 January 2014.

Bennell, Sheila, Chapter 2 "The development of ESDGC initiatives in Initial Teacher Education and Training in Wales", pp.29-56 in Citizenship Education in Wales, edited by Sheila Bennell, Shirley Egley, David Norcliffe and David Sullivan, School of Education and Lifelong Learning, 2011.

Bennell, Sheila and David Norcliffe, Chapter 1 "Education for Sustainable Development and Global Citizenship: a case study in policy formation”, pp.1-27 in Citizenship Education in Wales, edited by Sheila Bennell, Shirley Egley, David Norcliffe and David Sullivan, School of Education and Lifelong Learning, 2011.

Biesta, Gert, Chapter 30 "Citizenship Education" in pp.327-36 Scottish Education, Referendum, T. G. K. Bryce, W. M. Humes, D. Gillies and A. Kennedy (eds.), $4^{\text {th }}$ edition, Edinburgh, University of Edinburgh Press, 2013.

Cantle, Ted, Community Cohesion: A Report of the Independent Review Team Chaired by Ted Cantle, London, Home Office, 2001.

The Curriculum Review Group, A Curriculum for Excellence, Edinburgh, Scottish Executive, 2004.

Department for Children, Education, Lifelong Learning and Skills, Education for Sustainable Development and Global Citizenship, Information for Teacher Trainees and New Teachers in Wales, Cardiff, Welsh Assembly Government, July 2008, 40 p.

Department for Children, Education, Lifelong Learning and Skills, Personal and Social Education Framework for 7 to 19-year-olds in Wales, Cardiff, Welsh Assembly Government, July 2008, 26 p.

Department for Education, National Curriculum in England Framework Document, London, DfE, September 2013, 238 p. 
Department for Education, National Curriculum in England Key stages 3 and 4 Framework Document, London, DfE, September 2013, 82 p.

Department for Education, Citizenship Programmes of Study: Key Stages 3 and 4, London, DfE, 2013.

Diversity and Citizenship Curriculum Review Group, Diversity and Citizenship, London, DfES, 2007, $124 \mathrm{p}$.

Education Scotland, Corporate Plan 2013-2016, Transforming Lives through Learning, Livingston, Education Scotland, 2013, 62 p.

Electoral Commission, Scottish Independence Referendum, London, Electoral Commission, December 2014.

Ellison, Mark, BBC News, “Scottish independence: Councils bar 'Yes' and 'No' campaigns from schools", 22 August 2014, http://www.bbc.com/news/uk-scotland-scotland-politics-28803581. Garratt Dean and Piper Heather, "Citizenship Education in England and Wales: Theoretical Critique and Practical Considerations", Teachers and Teaching: Theory and Practice 14 (5-6), October-December 2008, pp.481-496.

Faulkner, Katherine, "Children will learn poetry and monarchs of England by heart under Tory plans”, Daily Mail, 6 March 2010.

Heater, Derek, Citizenship in Britain, A History, Edinburgh, Edinburgh University Press, 2006, 263 p.

Hepburn, Henry, “United they stand", Times Education Supplement Scotland, 15 June 2012.

Keating, Avril, David Kerr, Thomas Benton, Ellie Mundy and Joana Lopes, Citizenship Education in England 2001-2010: Young People's Practices and Prospects for the Future: The Eighth and Final Report from the Citizenship Education Longitudinal Study, London, DfE, 2010, 90 p.

Kemp, Jackie, "Scottish referendum: is it yes or no to politics in class?", The Guardian, 9 September 2014.

Kisby, Ben and James Sloam, "Citizenship, Democracy and Education in the UK: Towards a Common Framework for Citizenship Lessons in the Four Home Nations", Parliamentary Affairs, 65 (1), 2012, pp. 68-89.

Learning and Teaching Scotland, Developing Global Citizens within Curriculum for Excellence, Glasgow, Learning and Teaching Scotland, 2011, 32 p.

Local Government and Public Services Committee, 'Electoral Arrangements in Wales' Scrutiny Project, Cardiff, Welsh Assembly, 2006, 73 p.

McCauley, Kim, “Shaping Scotland's future”, Stride, Autumn-Winter 2014-15, http:// www.stridemagazine.org.uk/features/autumn-winter-2014-15/item/45-shaping-scotland-sfuture.

Northern Ireland Council for the Curriculum, Examinations and Assessment, Statutory Curriculum at Key Stage 3, Rationale and Detail, Belfast, Council for the Curriculum, Examinations and Assessment, 2007, $50 \mathrm{p}$.

Northern Ireland Council for the Curriculum, Examinations and Assessment, Learning for Life and Work, Guidance, Key Stage 3, Belfast, Council for the Curriculum, Examinations and Assessment, 2007, 2 p.

Northern Ireland Council for the Curriculum, Examinations and Assessment, Local and Global Citizenship Guidance for Key Stage 4, http://www.nicurriculum.org.uk/docs/key_stage_4/ areas_of_learning/learning_for_life_and_work/ks4_citizenship_guidance.pdf, 45 p. 
Northern Ireland Peace Agreement, <http://peacemaker.un.org/sites/peacemaker.un.org/files/ IE\%20GB_980410_Northern\%20Ireland\%20Agreement.pdf>.

Robertson, John W., Neil Blain and Paula Cowan, "Naming the First Minister: Scottish Adolescents' Knowledge and Perceptions of Political Decision Processes," Scottish Affairs, no.49, Autumn 2004.

Small, Chris, “Beyond tick-box citizenship”, Times Education Supplement Scotland, 12 August, 2011. Smith, Alan, "Citizenship Education in Northern Ireland: beyond national identity?", Cambridge Journal of Education, 33 (1), 2003, pp. 15-31.

Anne Beauvallet has been a senior lecturer at Toulouse-Jean Jaurès University since 2006. She has published several papers on British education policies and Chapter 11 ("Truancy and Anti-social Behaviour in England in the late Victorian Era and under New Labour") in Anti-social Behaviour in Britain: Victorian and Contemporary Perspectives (Sarah Pickard ed., Basingstoke, Palgrave, 2014).

\section{NOTES}

1. Derek, Heater, Citizenshp in Britain, A History, Edinburgh, Edinburgh University Press, 2006, pp.17-9.

2. Education for Citizenship and the Teaching of Democracy in Schools, Final Report of the Advisory Group on Citizenship. London, QCA, 1998.

3. This was praised in the 2001 Cantle Report (Community Cohesion: A Report of the Independent Review Team Chaired by Ted Cantle, London, Home Office, 2001, p.74).

4. Peter, Walker, "Gove's schools vision: back-to-basics with 'a thorough grounding for life'", The Guardian, 7 February 2013.

5. Northern Ireland Peace Agreement, http://peacemaker.un.org/sites/peacemaker.un.org/files/ IE\%20GB_980410_Northern\%20Ireland\%20Agreement.pdf, retrieved on 14 February 2016, p.20.

6. Northern Ireland Council for the Curriculum, Examinations and Assessment, Statutory Curriculum at Key Stage 3, Rationale and Detail, Belfast, Council for the Curriculum, Examinations and Assessment, 2007, p.3.

7. Northern Ireland Council for the Curriculum, Examinations and Assessment, Statutory Curriculum at Key Stage 3, Rationale and Detail, Belfast, Council for the Curriculum, Examinations and Assessment, 2007, p.7.

8. Department for Children, Education, Lifelong Learning and Skills, Personal and Social Education Framework for 7- to 19-year-olds in Wales, Cardiff, Welsh Assembly Government, July 2008, p.12.

9. The Curriculum Review Group, A Curriculum for Excellence, Edinburgh, Scottish Executive, 2004, p.12.

10. Learning and Teaching Scotland, Developing Global Citizens within Curriculum for Excellence, Glasgow, Learning and Teaching Scotland, 2011, p.5.

11. Chris, Small, "Beyond tick-box citizenship", Times Education Supplement Scotland, 12 August 2011.

12. Advisory Group on Citizenship, Education for Citizenship and the Teaching of Democracy in Schools, Final Report of the Advisory Group on Citizenship. London, QCA, 1998, p.8.

13. Diversity and Citizenship Curriculum Review Group, Diversity and Citizenship, London, DfES, 2007, p.8.

14. DfE, Citizenship Programmes of Study: Key Stages 3 and 4, 2013, p.3.

15. Learning for Life and Work, Guidance, Key Stage 3, Belfast, Council for the Curriculum, Examinations and Assessment, 2007, p.21. 
16. Northern Ireland Council for the Curriculum, Examinations and Assessment, Learning for Life and Work, Guidance, Key Stage 3, Belfast, Council for the Curriculum, Examinations and Assessment, 2007, p.5.

17. Lifelong Learning and Skills, Education for Sustainable Development and Global Citizenship, Information for Teacher Trainees and New Teachers in Wales, Cardiff, Welsh Assembly Government, July 2008, p.4.

18. Welsh Government, "Education for Sustainable Development and Global Citizenship (ESDGC)", updated on 4 May 2012, http://wales.gov.uk/topics/educationandskills/ allsectorpolicies/europeanandinternational/sustainabledevelop/?lang=en, retrieved on 25 January 2016.

19. Developing Global Citizens within Curriculum for Excellence, Glasgow, Learning and Teaching Scotland, 2011, p.10. In 2011, Learning and Teaching Scotland merged with Her Majesty's Inspectorate of Education to become Education Scotland, a Scottish Government executive agency.

20. Learning and Teaching Scotland, Developing Global Citizens within Curriculum for Excellence, Glasgow, Learning and Teaching Scotland, 2011, p.11.

21. Advisory Group on Citizenship, Education for Citizenship and the Teaching of Democracy in Schools, Final Report of the Advisory Group on Citizenship. London, QCA, 1998, p.8.

22. Department for Children, Education, Lifelong Learning and Skills, Personal and Social Education Framework for 7 to 19-year-olds in Wales, Cardiff, Welsh Assembly Government, July 2008, p.10.

23. Local and Global Citizenship Guidance for Key Stage 4, http://www.nicurriculum.org.uk/docs/ key_stage_4/areas_of_learning/learning_for_life_and_work/ks4_citizenship_guidance.pdf, p.8, retrieved on 10 February 2016.

24. Developing Global Citizens within Curriculum for Excellence, Glasgow, Learning and Teaching Scotland, 2011, p.12.

25. Ibid.

26. Personal and Social Education Framework for 7 to 19-year-olds in Wales, Cardiff, Welsh Assembly Government, July 2008, p.6.

27. "Education for Sustainable Development and Global Citizenship: a case study in policy formation", Citizenship Education in Wales, School of Education and Lifelong Learning, 2011, p.16.

28. Developing Global Citizens within Curriculum for Excellence, Glasgow, Learning and Teaching Scotland, 2011, p.12.

29. Learning and Teaching Scotland, Developing Global Citizens within Curriculum for Excellence, Glasgow, Learning and Teaching Scotland, 2011, p.13.

30. Learning and Teaching Scotland, Developing Global Citizens within Curriculum for Excellence, Glasgow, Learning and Teaching Scotland, 2011, p.18.

31. Northern Ireland Council for the Curriculum, Examinations and Assessment, Local and Global Citizenship Guidance for Key Stage 4, http://www.nicurriculum.org.uk/docs/key_stage_4/ areas_of_learning/learning_for_life_and_work/ks4_citizenship_guidance.pdf, p.7, retrieved on 12 February 2014.

32. Local and Global Citizenship Guidance for Key Stage 4, http://www.nicurriculum.org.uk/docs/ key_stage_4/areas_of_learning/learning_for_life_and_work/ks4_citizenship_guidance.pdf, retrieved on 12 February 2014, p.18.

33. Northern Ireland Council for the Curriculum, Examinations and Assessment, Local and Global Citizenship Guidance for Key Stage 4, http://www.nicurriculum.org.uk/docs/key_stage_4/ areas_of_learning/learning_for_life_and_work/ks4_citizenship_guidance.pdf, retrieved on 12 February 2014, p.11.

34. Northern Ireland Council for the Curriculum, Examinations and Assessment, Local and Global Citizenship Guidance for Key Stage 4, < http://www.nicurriculum.org.uk/docs/key_stage_4/ 
areas_of_learning/learning_for_life_and_work/ks4_citizenship_guidance.pdf>, retrieved on 12 February 2014, p.8.

35. Education for Citizenship and the Teaching of Democracy in Schools, Final Report of the Advisory Group on Citizenship. London, QCA, 1998, p.23.

36. Diversity and Citizenship Curriculum Review Group, Diversity and Citizenship, London, DfES, 2007, p.13.

37. Education for Citizenship and the Teaching of Democracy in Schools, Final Report of the Advisory Group on Citizenship. London, QCA, 1998, p.37.

38. DfE, National Curriculum in England Framework Document, London, DfE, September 2013, p.202.

39. Katherine, Faulkner, "Children will learn poetry and monarchs of England by heart under Tory plans", Daily Mail, 6 March 2010.

40. Education for Citizenship and the Teaching of Democracy in Schools, Final Report of the Advisory Group on Citizenship. London, QCA, 1998, p.55.

41. Diversity and Citizenship Curriculum Review Group, Diversity and Citizenship, London, DfES, 2007, p.10.

42. Debbie, Andalo, "MPs call for improved citizenship classes", The Guardian, 8 March 2007.

43. Education for Citizenship and the Teaching of Democracy in Schools, Final Report of the Advisory Group on Citizenship. London, QCA, 1998, p.8.

44. Quoted by John W. Robertson, Neil Blain and Paula Cowan, "Naming the First Minister: Scottish Adolescents' Knowledge and Perceptions of Political Decision Processes", Scottish Affairs, $\mathrm{n}^{\circ}$ 49, Autumn 2004.

45. Local Government and Public Services Committee, 'Electoral Arrangements in Wales' Scrutiny Project, Cardiff, Welsh Assembly, 2006, p.2.

46. Keating, Avril, David Kerr, Thomas Benton, Ellie Mundy and Joana Lopes, Citizenship Education in England 2001-2010: Young People's Practices and Prospects for the Future: The Eighth and Final Report from the Citizenship Education Longitudinal Study, London, DfE, 2010, p.iii.

47. Henry, Hepburn, "United they stand", Times Education Supplement Scotland, 15 June 2012.

48. Ibid.

49. Ibid.

50. "Citizenship, Democracy and Education in the UK: Towards a Common Framework for Citizenship Lessons in the Four Home Nations", Parliamentary Affairs, 65(1), 2012, p.80.

51. Gert, Biesta, Chapter 30 "Citizenship Education" in Scottish Education, Referendum, edited by T. G. K. Bryce, W. M. Humes, D. Gillies and A. Kennedy, $4^{\text {th }}$ edition, Edinburgh, University of Edinburgh Press, 2013, p.328.

52. Ibid., p.331.

53. Avril Keating, David Kerr, Thomas Benton, Ellie Mundy and Joana Lopes, Citizenship Education in England 2001-2010: Young People's Practices and Prospects for the Future: The Eighth and Final Report from the Citizenship Education Longitudinal Study, London, DfE, 2010, p.iv.

54. "Citizenship, Democracy and Education in the UK: Towards a Common Framework for Citizenship Lessons in the Four Home Nations", Parliamentary Affairs, 65(1), 2012, p.83.

55. "Citizenship Education in Northern Ireland: beyond national identity?", Cambridge Journal of Education, 33 (1), 2003, p.25.

56. An Evaluation of the Introduction of Local and Global Citizenship to the Northern Ireland Curriculum, quoted by Michael, Arlow, Chapter 6 "Education for local and global citizenship: the Northern Ireland experience" in Education Above All, Conference in Doha, Qatar, July 2012, p.96.

57. Michael, Arlow, Chapter 6 "Education for local and global citizenship: the Northern Ireland experience" in Education Above All, Conference in Doha, Qatar, July 2012, p.90.

58. Department for Education, National Curriculum in England Framework Document, London, DfE, September 2013, p.202. 
59. Garratt and Heather, "Citizenship Education in England and Wales: Theoretical Critique and Practical Considerations", Teachers and Teaching: Theory and Practice 14 (5-6), October-December 2008, p.484.

60. Ibid.

61. Ibid.

62. Education Scotland, Corporate Plan 2013-2016, Transforming Lives through Learning, Livingston, Education Scotland, 2013, p.60.

63. Ibid., p.58.

64. Julia, Belgutay, "Is independence debate too hot to handle in class?" Times Education Supplement Scotland, 17 January 2014.

65. Ibid.

66. Mark, Ellison, BBC News Online, "Scottish independence: Councils bar 'Yes' and 'No' campaigns from schools", 22 August 2014.

67. Quoted by Jackie, Kemp, "Scottish referendum: is it yes or no to politics in class?", The Guardian, 9 September 2014.

68. Kim, McCauley, “Shaping Scotland's future”, Stride, Autumn-Winter 2014-15.

69. Foreword by John McCormick, Electoral Commission, Scottish Independence Referendum, December 2014, p.1.

70. Electoral Commission, Scottish Independence Referendum, London, Electoral Commission, December 2014, pp.80, 64.

\section{ABSTRACTS}

Citizenship education at secondary school level across the UK is taught in different ways: as a statutory subject in England and Northern Ireland; as a non-statutory subject in Wales; as a cross-curricular theme in Scotland. The educational approach is didactic and subject-based in England whereas whole-school strategies and experiential learning have prevailed elsewhere. Citizenship education in Northern Ireland has stemmed from the need to establish a stable basis for peace. England, Wales and Scotland have considered it as a possible solution to the low participation of young people in politics but Wales and Scotland have also used CE to further their identities.

Au Royaume-Uni, dans l'enseignement secondaire, la citizenship education (comparable à certains égards à l'éducation civique française) constitue soit une matière obligatoire (en Angleterre et en Irlande du Nord), soit une matière optionnelle (au Pays de Galles), soit un thème transversal (en Écosse). L'enseignement est traditionnel en Angleterre tandis que des méthodes impliquant la participation des élèves en cours et dans l'organisation de l'école ont été préférées ailleurs. Si, en Irlande du Nord, cette matière est fondée sur le besoin d'établir une paix durable, dans le reste du Royaume-Uni elle a été mise en avant pour pallier le désengagement de la jeunesse du monde politique. L'Écosse et le Pays de Galles l'ont également utilisée pour promouvoir leur identité propre. 
INDEX

Keywords: citizenship education, England, Northern Ireland, Scotland, Wales

Mots-clés: éducation civique, Angleterre, Irlande du Nord, Écosse, Pays de Galles

\section{AUTHOR}

ANNE BEAUVALLET

CAS (EA801), Université Toulouse-Jean Jaurès 